\title{
The Importance of Environmental Materials in Learning Indonesian in Schools
}

\author{
Wiwi Noveria Husna. A \\ wiwinoveria@gmail.com
}

Humans can not be separated from environmental problems. This is in line with Nazarenko (in Ramadhan et al, 2019), which states that humans will always face environmental problems. Every human being in the world must experience environmental problems such as floods, forest fires, air pollution, and so on. The damage must have been caused by humans, so humans must be able to overcome it. According to Ramadhan et al (2019), environmental damage can threaten human life in the present and in the future. Environmental damage not only affects natural resources, but also human resources, such as economic problems that will occur later.

What can be done to overcome environmental problems is to instill awareness from an early age of the importance of protecting the environment so that the environment does not suffer damage. So, this certainly cannot be separated from the environmental education implemented in schools. According to Ramadhan et al (2019), environmental education aims to invite students to participate in protecting the environment. In line with that, according to Sukma et al (2020), the purpose of environmental education is to provide a positive view to students on how to respond to the environment well, and increase knowledge of nature. So that students understand how to be ethical towards the environment.

Environmental education can be applied in learning in schools, especially learning Indonesian. This is in line with Ramadhan et al (2019), which states that Indonesian language teachers are the luckiest teachers of other subjects, because Indonesian language teachers can increase students' reading interest, including regarding environmental issues. Thus, environmental damage can be anticipated from the age of the children.

Learning Indonesian cannot be separated from language skills, one of which is writing skills. Writing is the most important skill in education, but writing skill is a difficult skill, compared to other language skills. According to Ramadhan et al 2020, writing skills are not skills that are acquired naturally, but 
are learned. One of the factors that causes students' difficulty in writing is that students are less able to determine topics in writing. According to Sukma, Amelia, and Asma (2015), what can be done to involve students in finding resources in writing is to facilitate students to interact with the environment, so that students can actively participate in protecting the environment. Furthermore, according to Sukma and Safitri (2020), when writing use language that is easy to understand, and use topics related to certain environments.

One of the things that can inspire students when writing is to familiarize students with the environment. According to Ramadhan, Sari, and Hasanuddin (2013), in writing literary texts the writer can express his ideas creatively, where the work is adapted to environmental conditions. This shows that the writer cares about the environment around him. In line with that, according to Sukma et al (2020), in learning materials to write narrative text, students can write it based on what happens in the surrounding environment.

The existence of environmental material in Indonesian language learning, students can develop thinking skills. According to Ramadhan, and Tamsin Fitri, (2016), stated that with environmental material in Indonesian language learning, students will be invited to interact directly with the environment outside the classroom, so that students' intellectual abilities will develop. In line with that, according to Ramadhan, and Afnita, and Sulendari, (2013), with the problembased learning in Indonesian, students can face challenges in life in an increasingly complex environment.

Furthermore, the environmental material contained in Indonesian language learning can develop students' imaginative power in writing. This is in line with Ramdhan, Miaz, and Viodelf, (2018), where the use of an environmental approach in learning to write is proven to improve students' writing skills. According to Mulyasa (in Ramadhan, Miaz, and Viodelf, 2018), the environmental approach applied in Indonesian language learning can train students to observe what is happening in the surrounding environment, both inside the school environment and outside the school. Writing inspired by nature will motivate students to know everything about the natural environment. 
Based on the problems described above, the authors conducted research on the relationship between Indonesian language learning and the environment. This research was conducted by making 10 questions in the form of aquestionnaire google form. The results obtained from this study are as follows. The first statement is that environmental material is very important in Indonesian language learning, $41.9 \%$ strongly agree and $58.1 \%$ agree. The second statement is that the attitude to protect the environment is always applied during the learning process of Indonesian, 32.3\% strongly agree, 61, 3\% agree, 6.4\% disagree. The third statement is that in Indonesian language learning, environmental material is an interesting topic to study. $25,8 \%$ strongly agreed and $71 \%$ agreed.

Furthermore, the fourth statement is that with the presence of environmental material in text learning, students can increase their knowledge of the environment, $38.7 \%$ stated strongly agree and $61.3 \%$ agreed. The fifth statement is that in learning Indonesian, environmental materials can reduce student boredom in the teaching and learning process, $5.8 \%$ strongly agree, $64.5 \%$ strongly agree, and $9.7 \%$ disagree. The sixth statement is that the environmental material in Indonesian language learning makes it easier for students to express ideas in writing, so that students can improve their writing skills. $48.4 \%$ strongly agree, $48.4 \%$ agree, and $4.2 \%$ disagree. The seventh statement is that environmental preservation efforts can be made through reading texts in Indonesian language learning. 35.5\% strongly agree, 54.5\% agree, and 9.7\% disagree.

The eighth statement is that the teacher invites students to observe the community environment to make descriptive texts. $32.3 \%$ agree, $64.5 \%$ agree, and $3.2 \%$ disagree. The ninth statement reads, students are assigned to make observation reports about handling waste in their neighborhood, 32.3\% strongly agree, $58.1 \%$ agree, and $9.7 \%$ imply disagree. The tenth statement, namely providing environmental material in Indonesian language learning, is an effort to build ecological intelligence. $61.3 \%$ agree, $38.7 \%$ strongly agree.

Based on the results of this research, it can be concluded that environmental material is very important to be applied in learning Indonesian. 
With the existence ofmaterial environmentalin Indonesian language learning, students can build ecological intelligence. To apply these environmental materials, of course, we need teachers who can motivate students to love the environment. According to Ramadhan, Atmazaki, and Zulhafizh, (2013), teachers play an important role in creating a conducive learning environment. In addition, according to Sukma et al (2020), teachers are the most influential people in instilling environmental education from an early age. Teachers become role models for their students in the future, because student behavior is influenced by teacher behavior. 


\section{REFERENCE}

Ramadhan, S, et al. "Design of learning Modules Writing Narrative Text Based on Project Based Learning (PBL) by Using Mobile Devices. “JPhCS 1471.1 (2020): 012029.

Ramadhan., Afnita, \& A Yantama, S. P., (2018). Penerapan Pembelajaran Berbasis Masalah dalam Pembelajaran Teks Puisi untuk Siswa Kelas VIII SMP Negeri 4 Sungai Penuh. Pendidikan Bahasa Indonesia, 7(4), 104-114.

Ramadhan, S., Atmazaki, \& Zulhafizh. 2013. Kontribusi Sikap dan Motivasi Belajar Siswa Terhadap Hasil Belajar Bahasa Indonesia. Pendidikan Bahasa Indonesia. 1(2)

Ramadhan, S., Sari \&, Hasanuddun, W.S., (2013). Majas Lokalitas dalam Kumpulan Sajak Mangkutak di Negeri Prosaliris Karya Rusli Marzuki Saria. Bahasa, Sastra, dan Pembelajaran, 1(2)

Ramadhan, S., Sukma, E., \& Indriyani, V. (2019, August). Environmental education and disaster mitigation through language learning. In IOP Conference Series: Earth and Environmental Science (Vol. 314, No. 1, p. 012054). IOP Publishing.

Ramadhan., Tamsin, A. C, \& Fitri, Y., (2016). Pengaruh Model Pembelajaran Kooperatif Tipe Think Talk Write Berbantuan Media Gambar terhadap Keterampilan Menulis Karangan Argumentasi Siswa Kelas X SMA Negeri 5 Padang. Pendidikan Bahasa Indonesia, 5(2), 548-554.

Ramadhan, S., Viodelf, , R., \& Miaz, Y. (2018, April). Increasing writing skill of narrative and motivate students class IV primary school through environment approach. In International Conferences on Educational, Social Sciences and Technology (pp. 270-275). Fakultas Ilmu Pendidikan UNP.

Sukma, E., \& Annisa Safitri. 2020. Peningkatan Hasil Belajar Siswa pada Tema 3 Menggunakan Pendekatan Saintifik di Sekolah Dasar. Jurnal Pendidikan Tambusai (Vol. 4, No. 3) 
Sukma,E., Amelia, \& Asma. 2015. Pembelajaraan Menulis Laporan Percobaan Dengan Pendekatan Saintifik di Sekolah Dasar. In Prosiding Seminar Nasional Jurusan PGSD FIP UNP Tahun 2015 (Vol. 1, No. 1).

Sukma, E., Ramadhan, S., \& Indriyani, V. (2020, March). Integration of environmental education in elementary schools. In Journal of Physics: Conference Series (Vol. 1481, No. 1, p. 012136). IOP Publishing.

Sukma, E., Suriani, A., Putera, R. F., Habibi, M., Sukirno, T. 2020. Direct Writing Activity: A Strategy in Expanding Narrative Writing Skills for Elementary School. Universal Journal Of Educational Research, 8 (10), 4374-4383. 